\title{
Biometry and dissolution features of the benthic foraminifer Ammonia aomoriensis at high $\mathrm{pCO}_{2}$
}

\author{
Kristin Haynert $^{1, *}{ }^{,}$,oachim Schönfeld ${ }^{1}$, Ulf Riebesell ${ }^{1}$, Irina Polovodova ${ }^{2}$ \\ ${ }^{1}$ Leibniz-Institute of Marine Sciences, IFM-GEOMAR, Wischhofstrasse 1-3, 24148 Kiel, Germany \\ ${ }^{2}$ Department of Earth Sciences, University of Gothenburg, PO Box 460, 40530 Göteborg, Sweden
}

\begin{abstract}
Culturing experiments were performed with the benthic foraminifer Ammonia aomoriensis from Flensburg Fjord, western Baltic Sea. The experiments simulated a projected rise in atmospheric $\mathrm{CO}_{2}$ concentrations. We exposed specimens to 5 seawater $\mathrm{pCO}_{2}$ levels ranging from $618 \mu \mathrm{atm}(\mathrm{pH} 7.9)$ to $3130 \mu \mathrm{atm}(\mathrm{pH} 7.2)$ for $6 \mathrm{wk}$. Growth rates and mortality differed significantly among $\mathrm{pCO}_{2}$ treatments. The highest increase of mean test diameter $(19 \%)$ was observed at $618 \mu \mathrm{atm}$. At partial pressures $>1829 \mu \mathrm{atm}$, the mean test diameter was observed to decrease, by up to $22 \%$ at $3130 \mu \mathrm{atm}$. At $\mathrm{pCO}_{2}$ levels of 618 and $751 \mu \mathrm{atm}, A$. aomoriensis tests were found intact after the experiment. The outer chambers of specimens incubated at 929 and $1829 \mu$ atm were severely damaged by corrosion. Visual inspection of specimens incubated at $3130 \mu \mathrm{atm}$ revealed wall dissolution of all outer chambers, only their inner organic lining stayed intact. Our results demonstrate that $\mathrm{pCO}_{2}$ values of $\geq 929 \mu \mathrm{atm}$ in Baltic Sea waters cause reduced growth of $A$. aomoriensis and lead to shell dissolution. The bottom waters in Flensburg Fjord and adjacent areas regularly experience $\mathrm{pCO}_{2}$ levels in this range during summer and fall. Increasing atmospheric $\mathrm{CO}_{2}$ concentrations are likely to extend and intensify these periods of undersaturation. This may eventually slow down calcification in $A$. aomoriensis to the extent that net carbonate precipitation terminates. The possible disappearance of this species from the Baltic Sea and other areas prone to seasonal undersaturation would likely cause significant shifts in shallow-water benthic ecosystems in the near future.
\end{abstract}

KEY WORDS: Benthic foraminifera $\cdot$ Biometry $\cdot$ Test dissolution $\cdot$ Carbon dioxide $\cdot$ Baltic Sea

\section{INTRODUCTION}

The rise in atmospheric $\mathrm{CO}_{2}$ concentrations has caused an increase in seawater $\mathrm{pCO}_{2}$ over the past 250 yr (Takahashi 2004, Solomon et al. 2007). Surface ocean waters have taken up $\sim 30 \%$ of anthropogenic $\mathrm{CO}_{2}$ (Sabine et al. 2004, Khatiwala et al. 2009), causing a reduction in ocean $\mathrm{pH}$ and carbonate ion concentration (Orr et al. 2005, Cao \& Caldeira, 2008). In response to this acidification, the calcium carbonate saturation state for calcite and aragonite will be lowered to half their present-day values by 2300 (Feely et al. 2004, Caldeira \& Wickett 2005). This reduced saturation state and reduction in carbonate ion concentration is expected to negatively affect shell and skeleton construction by calcifying organisms (e.g. Erez 2003).

Benthic foraminifera are the most diverse group of hard-shelled protists. They live at the sediment-water interface, or within the sediments down to $>12 \mathrm{~cm}$ depth (Corliss 1985). Model calculations have inferred that benthic foraminifera account for from 5 to $30 \%$ of carbonate production in shallow waters (Wefer 1976, Langer 2008). The benthic foraminiferal fauna is estimated to precipitate $0.2 \mathrm{Gt} \mathrm{CaCO}_{3}$ per year on a global scale (Langer et al. 1997, Langer 2008), which amounts 
to about one-third of the production by planktonic foraminifers (Schiebel 2002).

In addition to $\mathrm{CO}_{2}$-induced ocean acidification, anthropogenic eutrophication by river and groundwater discharge and by atmospheric deposition can lead to changes in carbonate chemistry, especially in coastal marine environments such as the Baltic Sea (Rosenberg 1985, Conley et al. 2007, Levin et al. 2009, Borges \& Gypens 2010, Cossellu \& Nordberg 2010, Zhang et al. 2010). In comparison to the open ocean, the Baltic Sea exhibits lower salinities, lower $\left[\mathrm{CO}_{3}{ }^{2-}\right]$ and consequently lower calcium carbonate saturation states $(\Omega)$. In the western Baltic Sea, seasonal effects are superimposed (Hansen et al. 1999). Vertical stratification, enhanced microbial activity and the ensuing consumption of dissolved oxygen by the decay of particulate organic matter causes hypoxic conditions in the bottom water and therefore strong seasonally varying $\mathrm{pCO}_{2}$ values over the year (Diaz \& Rosenberg 2008, Conley et al. 2009, Thomsen et al. 2010). In response to low $\Omega$ and seasonal acidification, a reduced calcification of foraminifera is expected in Flensburg Fjord (Polovodova et al. 2009).

An increasing number of field and laboratory studies have shown that many calcareous organisms have lower calcification rates under simulated ocean acidification (e.g. Riebesell et al. 2000, Langdon \& Atkinson 2005, Orr et al. 2005, Moy et al. 2009, Thomsen \& Melzner 2010). There is also evidence that planktonic foraminifers precipitate thinner test walls at reduced carbonate ion concentrations and higher atmospheric $\mathrm{CO}_{2}$ levels (Spero et al. 1997, Bijma et al. 1999, Moy et al. 2009). A recent study by Kuroyanagi et al. (2009) investigated growth rates of the tropical, symbiontbearing foraminifer Marginopora kudakajimensis during long-term incubation at 4 different $\mathrm{pH}_{\mathrm{NBS}}$ (National Bureau of Standards pH) levels between 8.3 and 7.7. Their results indicated that growth rate, shell weight, and the number of newly added chambers decreased with a lowering of the $\mathrm{pH}$. A further culturing experiment with the benthic foraminifer Elphidium williamsoni indicated the formation of significantly thinner chamber walls at a pH of 7.6 (Allison et al. 2010). Specimens of the boreal shallow-water species Ammonia tepida were cultured under atmospheric $\mathrm{CO}_{2}$ concentrations of $120 \mu \mathrm{atm}(\mathrm{pH} 8.4)$ and $2000 \mu \mathrm{atm}(\mathrm{pH} 7.5$; Dissard et al. 2009). Surprisingly, the specimens still calcified at concentrations $<2000 \mu \mathrm{atm}$. This was in contrast to earlier experiments with living $A$. beccarii from Isle de Yeu, France. In the Ile de Yeu study, growth ceased and dissolution of the tests started at the same $\mathrm{pH}_{\mathrm{NBS}}$ of 7.5 (Le Cadre et al. 2003).

The consequences of future elevated atmospheric $\mathrm{CO}_{2}$ concentrations for benthic foraminiferal calcification in shallow waters are thus not sufficiently studied. The purpose of this study was to investigate the calcifi- cation response of the benthic foraminiferal Ammonia aomoriensis from the western Baltic Sea to different seawater $\mathrm{pCO}_{2}$ levels.

\section{MATERIALS AND METHODS}

Sampling and cultivation of foraminifera. Living Ammonia aomoriensis specimens were collected from Flensburg Fjord, western Baltic Sea $\left(54^{\circ} 48.082^{\prime} \mathrm{N}\right.$, $9^{\circ} 53.069^{\prime} \mathrm{E}, 13 \mathrm{~m}$ water depth), in June 2009. This location is situated $0.316 \mathrm{n}$ miles to the northwest of Station PF16-26, where, in June 2006, A. aomoriensis was reported (as $A$. beccarii) as dominating the living assemblages (Polovodova et al. 2009). The bottom sediment is a silty fine sand. We used a Mini Corer (inner diameter 100 mm; Kuhn \& Dunker 1994), deploying it from RV 'Littorina'. Altogether, 4 cores were taken. The first 2 cores were used for determination of carbonate system parameters and also to serve as backup material. Once aboard, the uppermost $1 \mathrm{~cm}$ of the third core was gently washed with seawater of 20 psu through a $63 \mu \mathrm{m}$ mesh. The residue was kept in $300 \mathrm{ml}$ Kautex wide-neck containers with seawater. The bottles were covered with Parafilm to avoid excess evaporation, and were then aerated and stored at $20^{\circ} \mathrm{C}$ as stock cultures. The cultures were exposed to a $12 \mathrm{~h}$ light:12 h dark (12:12 L/D) cycle. Foraminifera were fed with $200 \mu \mathrm{l}$ of a living algae mixture containing Nannochloropsis oculata, Phaeodactylum tricornutum and Chlorella (DT's Premium Blend) once a week. During feeding, the air pumps were switched off for 1.5 to $2 \mathrm{~h}$ to allow the algae to settle, and to facilitate successful feeding of the foraminifera.

Occurrence and identification of Ammonia species from Flensburg Fjord. In the western Baltic Sea, Ammonia spp. is common at 4 to $14 \mathrm{~m}$ water depth. It lives in muddy sands under brackish conditions with salinities ranging from 15 to 23 psu (Rottgardt 1952, Lutze 1965, Nikulina et al. 2008), and is found up to $6 \mathrm{~cm}$ deep in the sediment (Lutze 1987). Initially, Ammonia spp. from Kiel Bight and adjacent fjords were identified as Ammonia beccarii (Linné 1758), applying a broad understanding of this taxon (Schnitker 1974). Ammonia spp. from European marginal seas have in fact mostly been identified as Ammonia beccarii or Ammonia tepida (Haake 1962, Lutze 1965, Murray 1991, Debenay et al. 1998, Bouchet et al. 2007, Pascal et al. 2008). However, the diameter of our specimens from Flensburg Fjord was about 1.5 times larger than that of Ammonia tepida lectotypes from Puerto Rico (Cushman 1926, Hayward et al. 2003). The Flensburg Fjord specimens commonly had 9 chambers in the last whorl, while Ammonia tepida lectotypes showed only 7 chambers, and the outline of Flensburg 
Fjord tests was less lobular than those from Puerto Rico. Topotypes of Ammonia beccarii from Rimini Beach, Italy, were much flatter, had 14 to 15 chambers in the last whorl, and showed a distinct ornamentation on both spiral and umbilical sides (Hayward et al. 2004). Such ornamentation is lacking in our specimens from Flensburg Fjord. Ammonia specimens from Flensburg and Kiel Fjord were almost identical in shape and morphology (Polovodova \& Schönfeld, 2008). A molecular identification of Ammonia specimens collected in the Kiel Fjord with rDNA sequences revealed that they belong to the phylotype T6, which, based on morphological characters, was referred to the Pliocene species Ammonia aomoriensis (Asano 1951), which is likely to be extant (Hayward et al. 2004, Schweizer et al. 2010). The adjacent occurrence in the same marginal sea and the strong morphological similarity with specimens from Kiel Fjord suggests that Ammonia from Flensburg Fjord also represents the species A. aomoriensis. Ongoing molecular phylogenetic analysis by $M$. Schweizer, University of Edinburgh, is expected to provide more information about molecular identification of Flensburg Fjord Ammonia based on rDNA sequences.

Preparation of foraminifera. Living specimens were picked with a fine brush from the stock-cultures under a Wild M3C dissecting microscope. All individuals of Ammonia aomoriensis were divided into 3 groups of distinctively different behavior: small and 'active' young specimens (size class 150 to $250 \mu \mathrm{m}$ ), larger and 'active' young specimens (size class 250 to $350 \mu \mathrm{m}$ ) and 'inactive' 'old' specimens of $>200 \mu \mathrm{m}$ in diameter. The specimens were identified as being alive by their yellow cytoplasm content. Additionally, selected and presumably living specimens of 2 different size classes (150 to $250 \mu \mathrm{m}$ and 250 to $350 \mu \mathrm{m}$ ) were aligned in a

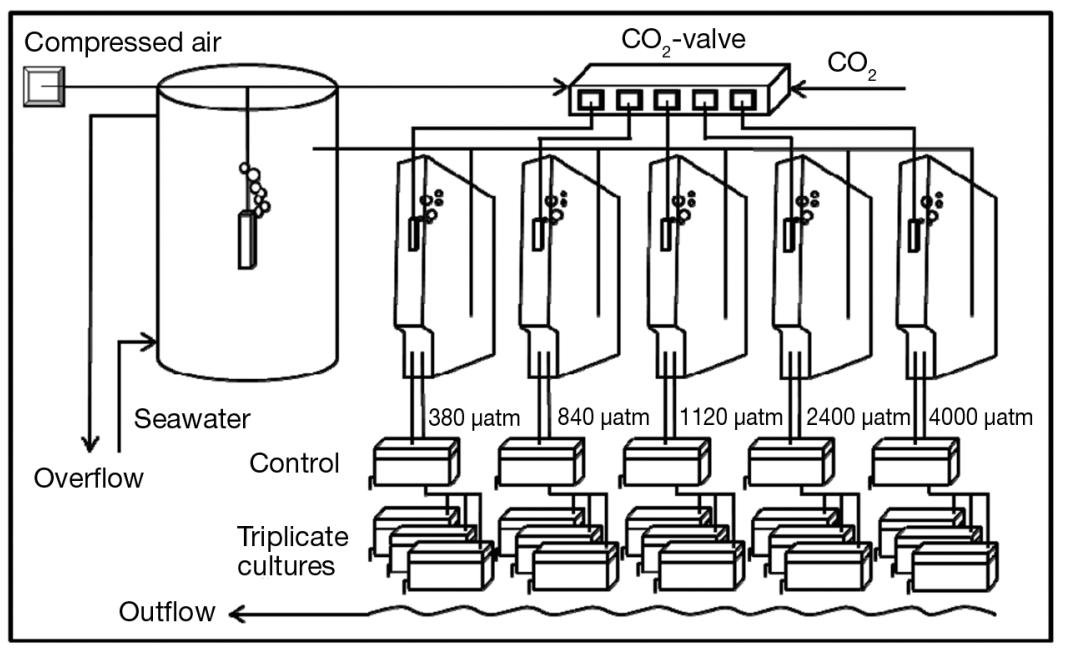

Fig. 1. Ammonia aomoriensis. Setup of culturing system. For explanation, see 'Experimental setup'
Petri dish and left for half an hour. This is an infallible method for distinguishing active from inactive individuals. Only those individuals that showed a lateral movement of at least $3 \mathrm{~mm}$ were considered active specimens. Larger, inactive specimens of $>200 \mu \mathrm{m}$ in diameter from both size classes showed a lateral movement of 0.5 to $1 \mathrm{~mm}$ only. These inactive specimens were adults, previously considered inappropriate for culturing (Barras et al. 2009).

All specimens, when we selected them, had the same stress condition, independent of activity level or size. We considered specimen movement - an individual and active response to disturbance of habitat - to be indicative of current physical condition, and on this basis we presumed physical condition to be the same for all specimens showing the same response behavior.

After their classification, the selected specimens were exposed to calcein-stained seawater $\left(4 \mathrm{mg} \mathrm{l}^{-1}\right)$ for 2 wk (Bernhard et al. 2004, Barras et al. 2009) and then placed into $300 \mathrm{ml}$ transparent polycarbonate culture vessels, 30 specimens to a vessel. Each vessel contained 10 small active, 10 larger active and 10 large inactive specimens (Fig. 1). This was done at 5 different $\mathrm{pCO}_{2}$ levels and 3 replicates for each $\mathrm{pCO}_{2}$ level and each size fraction.

Specimens were kept individually in $1 \mathrm{~mm}$ deep recruitment pits of $7 \mathrm{~mm}$ diameter, which were drilled into the base plate of the vessels. The recruitment pits were not enclosed, so that the specimens could move and seek shelter inside the pits. The basic idea was that the recruitment pits would help us locate the specimens for monitoring. We observed that most specimens moved around only within their pits, with only very few leaving the pits. (It might have been better to have had deeper or more enclosed pits, but this in turn might have caused a more unstable $\mathrm{pCO}_{2}$ gradient in each pit.) A small amount (0.43 g) of carbonate-free quartz (>97\% $\left.\mathrm{SiO}_{2}\right)$ was dispersed in equal amounts among the pits with the intention of better mimicking the natural habitat of Ammonia aomoriensis. The microenvironment along the base plate of the vessel appeared to be less attractive to the specimens, since most of them stayed in their pit.

Experimental setup. Culturing of Ammonia aomoriensis was performed in a flow-through system following the concept of Hintz et al. (2004) (Fig. 1). The culture vessels were flushed with cartridgefiltered $(25 \mu \mathrm{m})$ and UV-sterilized seawater from Kiel Fjord. In order to monitor the carbonate system, pH according to the National Bureau of Standards $\mathrm{pH}$-scale $\left(\mathrm{pH}_{\mathrm{NBS}}\right)$, total alkalinity 
$\left(A_{T}\right)$, salinity, temperature and phosphate concentrations $\left(\mathrm{PO}_{4}{ }^{3-}\right)$ were measured continuously in the flow-through system. The seawater was enriched with oxygen in a 301 reservoir bin, and subsequently conditioned in five 51 compact jerrycans with $\mathrm{CO}_{2}$-enriched compressed air at partial pressures of 380, 840, 1120, 2400 and $4000 \mu \mathrm{atm}$. The $\mathrm{pCO}_{2}$ range from 380 to $1120 \mu \mathrm{atm}$ corresponded to values recorded in Flensburg Fjord; the 2 higher levels were meant to simulate future scenarios of 2400 and $4000 \mu \mathrm{atm}$. The preconditioned seawater from each jerrycan flowed through 4 culture vessels. Three vessels contained living foraminifera as triplicate experiments at the same $\mathrm{pCO}_{2}$ exposure, and 1 vessel was left barren as a control for hydro-chemical monitoring. To replace the water in the aquaria 1.4 times $\mathrm{h}^{-1}$, the flow rate was adjusted to $0.16 \mathrm{ml} \mathrm{s}^{-1}$. The overflow seeped through the fissure between lid and vessel, draining off to a sink. Food was added every second day to the vessels containing foraminifera as $100 \mu \mathrm{l}$ DT's Premium Blend algae mixture. The experiment lasted $6 \mathrm{wk}$.

Population dynamics and biometry. The aquariumlike culture vessels permitted monitoring of the individuals throughout the experiment. They were examined weekly under a dissecting microscope, and their presence, shape and behavior noted. As the removal of culture vessels from the experimental setup for examination induced some disturbance, we refrained from surveillance at shorter intervals. Using an eyepiece reticle on the dissecting microscope, we measured the size of all specimens weekly in their recruitment pits. These measurements had to be made through the water column in the culture vessels. During these measurements, temperature was held stable by placing the culture vessel in a water bath with crushed ice, and monitoring the temperature.

Because of a working distance of $>50 \mathrm{~mm}$, we could use only $40 \times$ magnification, which resulted in an error of $\pm 12.5 \mu \mathrm{m}$ (maximum distance to the next scale unit) in the size measurements. This is approx. \pm 4 to $\pm 7 \%$ of the average diameter (from 180 to $280 \mu \mathrm{m}$ ) of the examined specimens. The overall test diameter of specimens changed during the experiment. Size differences were calculated by measuring the test diameter at the beginning and at the end of the $6 \mathrm{wk}$ experiment. In addition to diameter measurements, we determined the number of new chambers formed during the incubation period. We did this at the end of the experiment by examining the specimens (according to Dissard et al. 2009) under an inverted fluorescence microscope (Zeiss Axiovert 100, wavelength: $530 \mathrm{~nm})$.
After the experiment, all individuals were stained with Rose Bengal to assess whether they still contained cytoplasm (indicating living specimens) or not (dead specimens).

Water chemistry. $\mathrm{pH}$, as well as alkalinity, salinity, temperature and phosphate concentrations, were measured and compared in the culture vessels and controls. As an additional control we measured all parameters in the 301 reservoir bin, in the five 51 compact jerrycans and in the sink. $\mathrm{pH}_{\mathrm{NBS}}$, temperature and salinity were monitored every second day in the setup. We used a WTW 340i pH analyzer to measure $\mathrm{pH}$ and water temperature. The $\mathrm{pH}$ analyzer was calibrated with standard buffer solutions of $\mathrm{pH} 4.01,7.00$ and 10.00 (WTW standard, DIN/NIST buffers L7A). Precision was \pm 0.01 for $\mathrm{pH}$ and $\pm 0.1^{\circ} \mathrm{C}$ for temperature. For salinity measurements, a WTW Cond 315 i salinometer with a precision of \pm 0.1 psu was used.

In order to calculate carbonate system parameters with $\mathrm{CO}_{2} \mathrm{SYS}$ software, the phosphate concentration was measured weekly (Lewis \& Wallace 1998). A $10 \mathrm{ml}$ water sample was passed through a $0.2 \mu \mathrm{m}$ filter and was measured colorimetrically in a spectrophotometer (U 2000, Hitachi-Europe) at a wavelength of $882 \mathrm{~nm}$ according to Koroleff (1983). The precision of the phosphate measurements was $\pm 0.2 \mu \mathrm{mol} \mathrm{l}^{-1}$.

Samples for analysis of total alkalinity $\left(A_{\mathrm{T}}\right)$ were sterile-filtered (0.2 $\mathrm{mm}$ pore size) and determined through potentiometric titration (Dickson, 1981) in a Metrohm Tiamo automatic titration device. The precision of the alkalinity measurements was $2 \mu \mathrm{mol} \mathrm{kg}{ }^{-1}$. The carbonate system parameters $\mathrm{pCO}_{2}$ and $\Omega$ calcite values were calculated from measured $\mathrm{A}_{\mathrm{T}}, \mathrm{pH}$, phosphate, temperature and salinity using the $\mathrm{CO}_{2} \mathrm{SYS}$ software (Lewis \& Wallace 1998). The equilibrium constants of Mehrbach et al. (1973), as refitted by Dickson \& Millero (1987), were chosen.

Table 1. Ammonia aomoriensis. Carbonate chemistry of bottom water from sampling station FF3 from Flensburg Fjord (54 $\left.48.082^{\prime} \mathrm{N}, 9^{\circ} 53.069^{\prime} \mathrm{E}\right)$, showing duplicate average values of salinity, temperature, total alkalinity $\left(\mathrm{A}_{\mathrm{T}}\right)$ and the $\mathrm{pH}$ according to the National Bureau of Standards $\mathrm{pH}$-scale $\left(\mathrm{pH}_{\mathrm{NBS}}\right)$. The precision of the alkalinity measurements was $100 \mu \mathrm{mol} \mathrm{kg}{ }^{-1}$. Carbon dioxide partial pressure $\left(\mathrm{pCO}_{2}\right)$ and Omega of calcite saturation state $\left(\Omega_{\mathrm{ca}}\right)$ were calculated (cal) with the $\mathrm{CO}_{2}$ Sys program (Lewis \& Wallace 1998) from measured $\mathrm{A}_{\mathrm{T}}, \mathrm{pH}_{\mathrm{NBS}}$, temperature and salinity

\begin{tabular}{|lrrrrrr|}
\hline $\begin{array}{l}\text { Date } \\
(\mathrm{d} / \mathrm{mo} / \mathrm{yr})\end{array}$ & Salinity & $\begin{array}{c}\text { Temp. } \\
\left({ }^{\circ} \mathrm{C}\right)\end{array}$ & $\begin{array}{c}\mathrm{A}_{\mathrm{T}} \\
\left(\mu \mathrm{mol} \mathrm{kg}^{-1}\right)\end{array}$ & $\mathrm{pH}_{\mathrm{NBS}}$ & $\begin{array}{r}\mathrm{pCO}_{2} \text { cal } \\
(\mu \mathrm{atm})\end{array}$ & $\Omega_{\text {ca }}$ cal \\
\hline $03 / 06 / 09$ & 20.2 & 10.3 & $2125.5 \pm 87.6$ & 7.83 & 727.1 & 1.35 \\
$18 / 08 / 09$ & 19.8 & 15.3 & $2239.1 \pm 28.0$ & 7.47 & 1863.3 & 0.85 \\
$20 / 10 / 09$ & 21.6 & 11.9 & $2465.7 \pm 31.4$ & 7.31 & 2873.8 & 0.60 \\
$07 / 12 / 09$ & 20.9 & 8.8 & $2174.0 \pm 64.1$ & 7.81 & 769.1 & 1.42 \\
$15 / 02 / 10$ & 16.9 & -0.4 & $1804.6 \pm 200.7$ & 7.94 & 465.1 & 1.05 \\
$19 / 04 / 10$ & 18.8 & 5.6 & $2374.9 \pm 90.8$ & 7.94 & 493.0 & 2.01 \\
\hline
\end{tabular}


Near-bottom water samples were taken from Flensburg Fjord in order to determine salinity, temperature, $\mathrm{pH}$ and alkalinity in the natural habitat of Ammonia aomoriensis. The range of reproducibility of $\mathrm{pH}$ measurements from Flensburg Fjord bottom-water samples, collected bi-monthly from June 2009 to April 2010, was from 0.04 to 0.1 . Carbonate system parameters were calculated from measurements of $\mathrm{pH}_{\mathrm{NBS}}$ and alkalinity. Monitoring results will be reported elsewhere, but we refer to the $\mathrm{pCO}_{2}$ values and their seasonal range in the present study (Table 1).

Preparation for scanning electron microscopy. At the end of the experiment, the foraminifers were removed from the culture vessels using a fine brush and were transferred to Eppendorf-type micro centrifuge tubes. Fixation was accomplished in a solution of $2 \mathrm{~g}$ Rose Bengal in 11 ethanol (98\%, technical quality) for $24 \mathrm{~h}$. Finally, intact specimens were air-dried, prepared with an Emitech K550 (Au+Pd) sputter coater and photographed with a scanning electronic microscope (SEM; Cam Scan-CS-44).

Statistics. Changes in test diameter (see Fig. 3B) were analyzed by linear regression $(f=b+a x)$ using SIGMA PLOT 10. Regression lines present Pearson correlation with confidence bands, which exhibit 95\% $\mathrm{CI}$ and correlation coefficient $\mathrm{R}^{2}$ for the fitted line. The error in the regression equations is $\pm 1 \mathrm{SE}$ of the mean.

\section{RESULTS}

\section{Water chemistry}

Salinity ranged from 17 to $19.5 \mathrm{psu}$ (mean $\pm \mathrm{SE}=$ $18.4 \pm 0.8$ ) during the experimental period (Fig. 2, Table 2). Mean seawater temperature in the culture

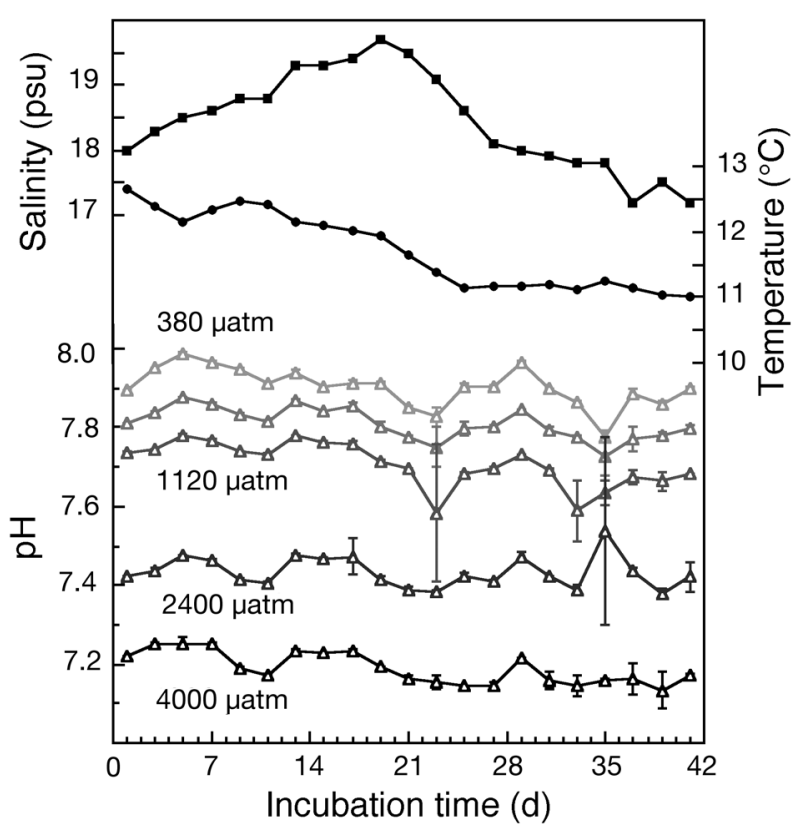

Fig. 2. Ammonia aomoriensis. Water chemistry during the experiment. Temperature and salinity are mean values of all measurements taken in each culture vessel flushed with different seawater $\mathrm{pCO}_{2}$ levels as in Table 1. $\mathrm{pH}$ : means $\pm \mathrm{SD}$, $\mathrm{n}=3$

vessels decreased steadily over the course of the experiment from 12.6 to $11^{\circ} \mathrm{C}$. The culture vessels were flushed with seawater, which was taken from Kiel Fjord with our aquarium system. Salinity and temperature of seawater changed seasonally (Thomsen et al. 2010). The fluctuations of these parameters during the experimental period therefore correspond to the natural variability in Ammonia aomoriensis habitat.

$\mathrm{pH}$ values (mean $\pm 1 \mathrm{SE}$ ) varied according to seawater $\mathrm{pCO}_{2}$ from $7.9 \pm 0.05$ to $7.2 \pm 0.04$. They were

Table 2. Ammonia aomoriensis. Carbonate chemistry of culture media, means $\pm \mathrm{SD}(\mathrm{n}=3)$ of several variables for $5 \mathrm{pCO}_{2}$ levels. Controls are mean values of all measurements made during the 6 wk incubation. $\mathrm{pCO}_{2}$, total carbon $\left(\mathrm{C}_{\mathrm{T}}\right)$, and Omega of calcite saturation state $\left(\Omega_{\mathrm{ca}}\right)$ were calculated (cal) with the $\mathrm{CO}_{2}$ Sys program (Lewis \& Wallace 1998) from measured $\mathrm{A}_{\mathrm{T}}, \mathrm{pH}_{\mathrm{NBS}}, \mathrm{PO}_{4}{ }^{3-}$, temperature and salinity

\begin{tabular}{|c|c|c|c|c|c|c|c|c|}
\hline $\begin{array}{l}\mathrm{pCO}_{2} \text { baseline } \\
\text { level ( } \mu \mathrm{atm})\end{array}$ & $\begin{array}{c}\mathrm{pCO}_{2} \mathrm{cal} \\
(\mu \mathrm{atm})\end{array}$ & Salinity & $\begin{array}{l}\text { Temp. } \\
\left({ }^{\circ} \mathrm{C}\right)\end{array}$ & $\mathrm{pH}_{\mathrm{NBS}}$ & $\begin{array}{c}A_{\mathrm{T}} \\
\left(\mu \mathrm{mol} \mathrm{kg}{ }^{-1}\right)\end{array}$ & $\begin{array}{c}C_{\mathrm{T}} \mathrm{cal} \\
\left(\mu \mathrm{mol} \mathrm{kg} \mathrm{kg}^{-1}\right)\end{array}$ & $\Omega_{\mathrm{ca}} \mathrm{Cal}$ & $\begin{array}{c}\mathrm{PO}_{4}{ }^{3-} \\
\left(\mu \mathrm{mol} \mathrm{l} l^{-1}\right)\end{array}$ \\
\hline 380 & $617.9 \pm 8.5$ & $18.4 \pm 0.8$ & $11.8 \pm 0.6$ & $7.90 \pm 0.05$ & $2040.1 \pm 20.7$ & $1980.2 \pm 31.8$ & $1.66 \pm 0.25$ & $0.99 \pm 0.33$ \\
\hline 380_control & $610.1 \pm 94.0$ & $18.4 \pm 0.8$ & $11.7 \pm 0.6$ & $7.91 \pm 0.04$ & $2043.1 \pm 20.1$ & $1983.1 \pm 29.2$ & $1.67 \pm 0.22$ & $0.99 \pm 0.31$ \\
\hline 840 & $751.1 \pm 22.8$ & $18.4 \pm 0.8$ & $11.6 \pm 0.6$ & $7.81 \pm 0.04$ & $2039.0 \pm 17.4$ & $1999.5 \pm 22.3$ & $1.38 \pm 0.16$ & $1.02 \pm 0.32$ \\
\hline 840_control & $734.7 \pm 67.8$ & $18.4 \pm 0.8$ & 0.7 & $7.81 \pm 0.04$ & $2036.0 \pm 16.7$ & 1996. & $1.39 \pm 0.14$ & 1.04 \\
\hline 1120 & $929.1 \pm 23.4$ & $18.4 \pm 0.8$ & $11.7 \pm 0.6$ & $7.71 \pm 0.06$ & $2035.2 \pm 19.8$ & $2014.4 \pm 23.2$ & $1.14 \pm 0.13$ & $1.01 \pm 0.33$ \\
\hline 1120_control & $953.9 \pm 147.4$ & $18.4 \pm 0.8$ & $11.6 \pm 0.5$ & $7.71 \pm 0.04$ & $2034.0 \pm 14.6$ & $2018.0 \pm 19.2$ & $1.12 \pm 0.15$ & $1.06 \pm 0.32$ \\
\hline 2400 & $1829.2 \pm 33.5$ & $18.4 \pm 0.8$ & $11.6 \pm 0.6$ & $7.43 \pm 0.04$ & $2036.2 \pm 21.5$ & $2075.2 \pm 20.4$ & $0.64 \pm 0.08$ & 1.01 \\
\hline 2400_control & $1891.2 \pm 227.0$ & $18.4 \pm 0.8$ & $11.6 \pm 0.6$ & $7.42 \pm 0.04$ & $2042.0 \pm 14.6$ & $2095.7 \pm 21.0$ & $0.59 \pm 0.06$ & $1.00 \pm 0.30$ \\
\hline 4000 & $3130.2 \pm 33.6$ & $18.4 \pm 0.8$ & $11.9 \pm 0.5$ & $7.19 \pm 0.04$ & $2039.7 \pm 19.2$ & $2156.2 \pm 24.5$ & $0.37 \pm 0.04$ & $1.00 \pm 0.33$ \\
\hline 4000_control & $3158.6 \pm 235.1$ & $18.4 \pm 0.8$ & $11.8 \pm 0.5$ & $7.18 \pm 0.05$ & $2036.9 \pm 17.8$ & $2159.8 \pm 23.7$ & $0.36 \pm 0.03$ & $0.96 \pm 0.37$ \\
\hline
\end{tabular}


reasonably stable during the whole incubation time and did not mirror variations in salinity and temperature (Fig. 2). Maxima and minima in mean values were caused by a few exceptionally high and low values in single replicates, which may represent measurement errors. Alkalinity and phosphate concentration also showed no significant change over the course of the experiment (Table 2). No systematic offsets or significant differences among experimental and control vessels were detected. While respiration and degradation processes are likely to be enhanced when food is added to the vessels, we saw no significant differences of measured or calculated parameters between controls and cultures. This suggests that the amount of food added was too small to change the abiotic conditions in the culture vessels at the given flow rates.

The calculated $\mathrm{pCO}_{2}$ in the culture vessels differed significantly from the $\mathrm{pCO}_{2}$ baseline level in the compressed air (Table 2). For instance, in the jerrycan bubbled with compressed air without $\mathrm{CO}_{2}$ addition, which should yield the ambient atmospheric partial pressure of $380 \mu \mathrm{atm}$, the measured value was $618 \mu \mathrm{atm}$. This was most likely due to a higher $\mathrm{CO}_{2}$ concentration in subsurface waters of Kiel Fjord at the seawater system intake caused by seasonal phenomena, such as upwelling of hypoxic and hypercapnic waters (Thomsen et al. 2010). At higher $\mathrm{pCO}_{2}$ levels, the measured values in the culture vessels were 11 to $24 \%$ lower than the target values in the $\mathrm{CO}_{2}$-charged compressed air (Table 2). The difference probably accounts for outgassing in the culture vessels due to the slow percolation rate. In the following, we refer to the $\mathrm{pCO}_{2}$ values that were calculated from actually measured hydrochemical parameters in the culture vessels and not to the pre-adjusted values in the $\mathrm{CO}_{2}$-enriched air (Table 2).

The $\Omega$ values (mean $\pm 1 \mathrm{SE}$ ) for calcite ranged from $1.66 \pm 0.25$ at a $\mathrm{pCO}_{2}$ of $618 \mu$ atm to $0.37 \pm 0.04$ at a $\mathrm{pCO}_{2}$ of $3130 \mu \mathrm{tm}$. The values $<1.0$ indicate carbonate dissolution at partial pressures above $929 \mu$ atm under the present settings of temperature and salinity.

The carbonate system parameter $\mathrm{pCO}_{2} \mathrm{cal}$ and $\Omega_{\mathrm{Ca}}$ $\mathrm{cal}$, as calculated from measured $\mathrm{pH}_{\mathrm{NBS}}$ and $\mathrm{A}_{\mathrm{T}}$ values, varied in the near-bottom water at the sampling site in Flensburg Fjord from $2874 \mu \mathrm{atm}(\mathrm{pH} 7.3)$ in October 2009 to 465 uatm (pH 7.9) in February 2010 (Table 1). In August and October 2009, $\Omega$ values for calcite were temporarily $<1.0$ ( 0.85 and 0.6 , respectively). Therefore, our experiment covers the entire seasonal $\mathrm{pCO}_{2}$ variability in the A. aomoriensis habitat in Flensburg Fjord, even though we did not capture the seawater $\mathrm{pCO}_{2}$ level in February and April 2010 when the $\mathrm{pCO}_{2}$ in Flensburg Fjord was 130 patm lower than at the lowest partial pressure in our experiment.

\section{Test diameters}

All specimens, whether inactive or active, were alive at the beginning of the experiment. They grew during the incubation, especially at low $\mathrm{pCO}_{2}$ values. Active specimens from the 150 to $250 \mu \mathrm{m}$ fraction displayed an increase of $19 \%$ in diameter at a $\mathrm{pCO}_{2}$ of $618 \mu \mathrm{atm}$, whereas mean diameter of active specimens from the 250 to $350 \mu \mathrm{m}$ fraction increased by only $11 \%$ (Fig. 3A). In comparison to active specimens, the mean diameter of the large inactive specimens $(>200 \mu \mathrm{m})$ increased by only $2 \%$ at a $\mathrm{pCO}_{2}$ of $618 \mu$ atm during the course of the experiment (Fig. 3A).

The growth of specimens from the 150 to $250 \mu \mathrm{m}$ fraction differed significantly, depending on $\mathrm{pCO}_{2}$ treatment (Fig. 3B). The greatest increase in mean shell diameter of $35 \mu \mathrm{m}$ was observed at the lowest $\mathrm{pCO}_{2}$ level of $618 \mu \mathrm{atm}$. At $\mathrm{pCO}_{2}$ levels of $751 \mu \mathrm{atm}$ and $929 \mu \mathrm{atm}$, the mean diameter of Ammonia aomoriensis increased by only 29 and $13 \mu \mathrm{m}$, respectively. At a $\mathrm{pCO}_{2}$ of 1829 and $3130 \mu \mathrm{atm}$, the test diameter was reduced by 5 and $41 \mu \mathrm{m}$ due to test corrosion.

The shell diameter of active specimens from the 250 to $350 \mu \mathrm{m}$ fraction differed also according to $\mathrm{pCO}_{2}$ level (Fig. 3B). At a $\mathrm{pCO}_{2}$ of $618 \mu \mathrm{atm}$, the mean shell diameter increased by $29 \mu \mathrm{m}$. The growth rate was highest at a $\mathrm{pCO}_{2}$ of $751 \mu \mathrm{atm}$, where the increase was $39 \mu \mathrm{m}$. Ammonia aomoriensis displayed a reduced growth under higher $\mathrm{pCO}_{2}$ levels, viz. from 929 to $3139 \mu \mathrm{atm}$. While the mean shell diameter increased by $29 \mu \mathrm{m}$ at a $\mathrm{pCO}_{2}$ of $929 \mu \mathrm{atm}$, the specimens displayed barely any change in size at a $\mathrm{pCO}_{2}$ of $1829 \mu \mathrm{atm}$ during the $6 \mathrm{wk}$ incubation period. At a seawater $\mathrm{pCO}_{2}$ of $3130 \mu \mathrm{atm}$ the average shell diameter was reduced by $23 \mu \mathrm{m}$.

Inactive specimens from the $>200 \mu \mathrm{m}$ fraction showed only a slight change of test diameter at a $\mathrm{pCO}_{2}$ of from 618 to $1829 \mu \mathrm{atm}$ (Fig. 3B). The lowest increase $(6 \mu \mathrm{m})$ was observed at a $\mathrm{pCO}_{2}$ of $618 \mu \mathrm{atm}$, followed by an increase of $21 \mu \mathrm{m}$ at a $\mathrm{pCO}_{2}$ of $751 \mu \mathrm{atm}$ and $13 \mu \mathrm{m}$ at $929 \mu \mathrm{atm}$. Like active specimens, the shell diameter barely changed at a $\mathrm{pCO}_{2}$ of $1829 \mu \mathrm{atm}$ and, on average, decreased by $48 \mu \mathrm{m}$ at a $\mathrm{pCO}_{2}$ of 3130 uatm.

\section{Loss and mortality rates}

During the 6 wk incubation period, some Ammonia aomoriensis specimens disappeared between weekly surveillance periods (Fig. 4). On these occasions the entire culture vessel was thoroughly screened twice for lost specimens. However, the missing individuals had neither moved out of their recruitment pits, nor had they crawled upwards on the sidewalls of the 
A

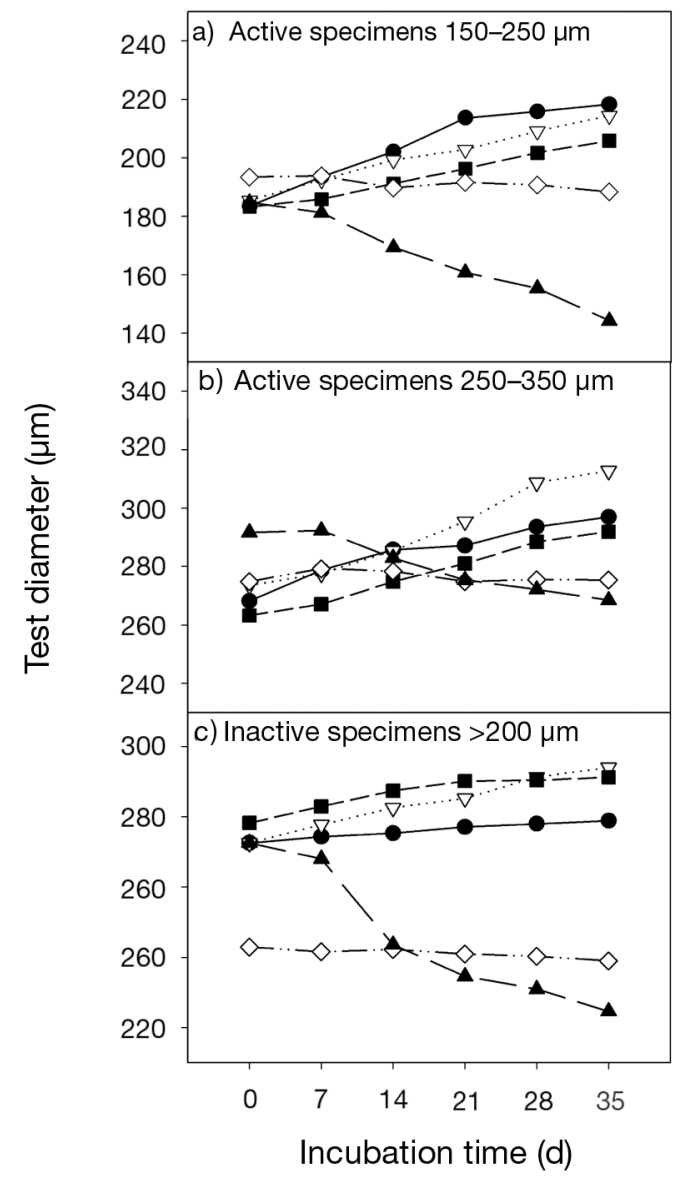

B

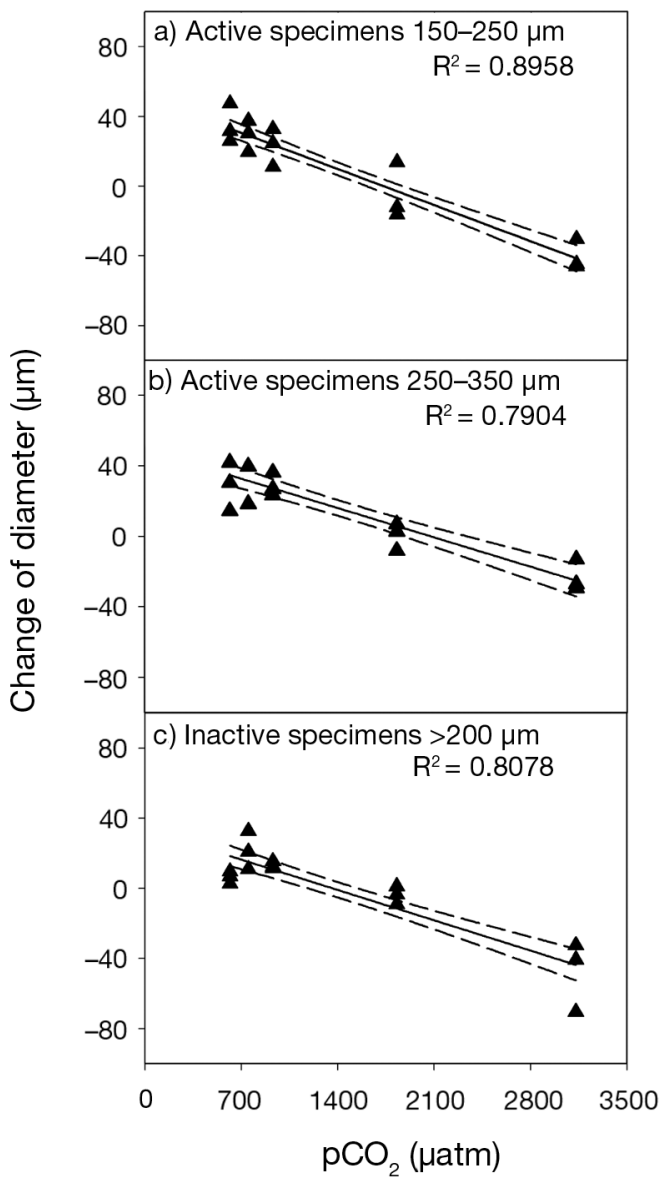

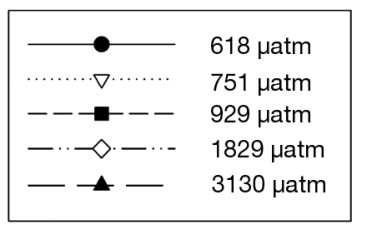

Fig. 3. Ammonia aomoriensis. Change of test diameter (A) over time, and (B) in relation to $5 \mathrm{pCO}_{2}$ treatments for 3 size fractions, including both active and inactive specimens. Each symbol in (A) and (B) represents the average of triplicate culture vessels. Solid lines in $(B)=$ linear regression curves $(f=b+a x)$ of diameter change; dashed lines $=95 \%$ CI

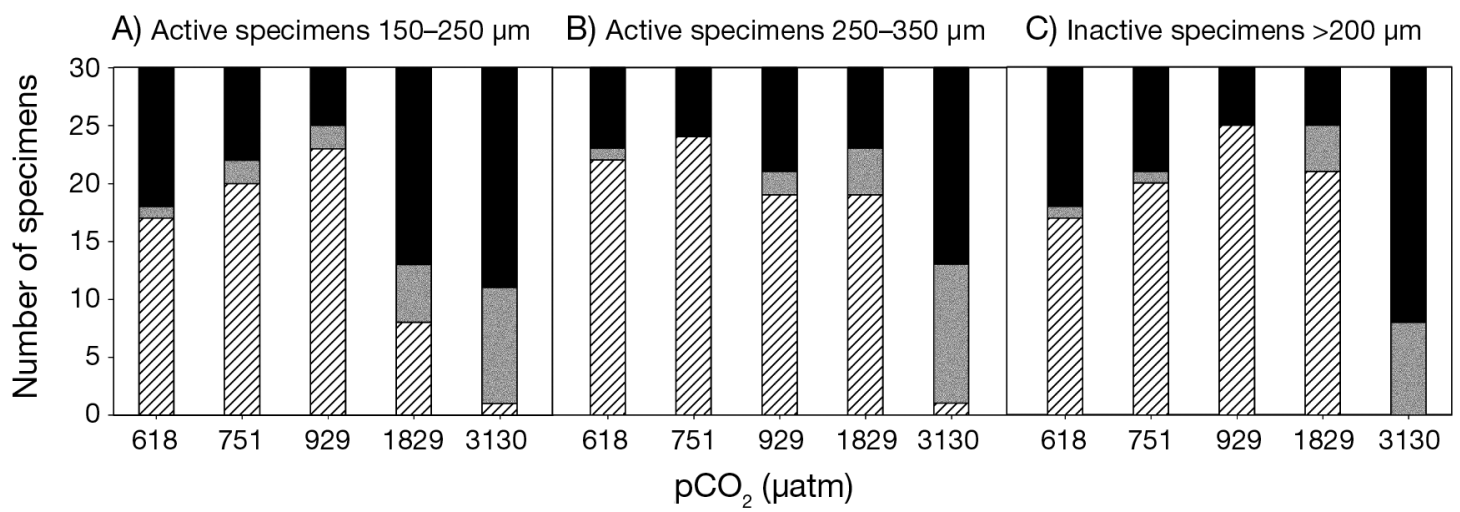

Lost specimens

Dead specimens [IIIJ Living specimens
Fig. 4. Ammonia aomoriensis. Loss and mortality versus $\mathrm{pCO}_{2}$ level for 3 size fractions $(A, B, C)$, including both active and inactive specimens. Bars display means of lost, dead and live specimens 
vessels (e.g. Lee \& Anderson 1993). Nor were encystation or clustering of juveniles around the mother individual observed (e.g. Lehmann 2000, Heinz et al. 2005). The physical disturbance during removal of vessel, surveillance and sampling might have played a role in this occurrence. Allison et al. (2010), moreover, have described the possibility of flotation and escape of specimens attached to air bubbles with seawater outflow from the cultivation chambers. The inner organic lining, which is light and floats easily, may also be involved in escape by flotation. In our setup, however, air bubbles were

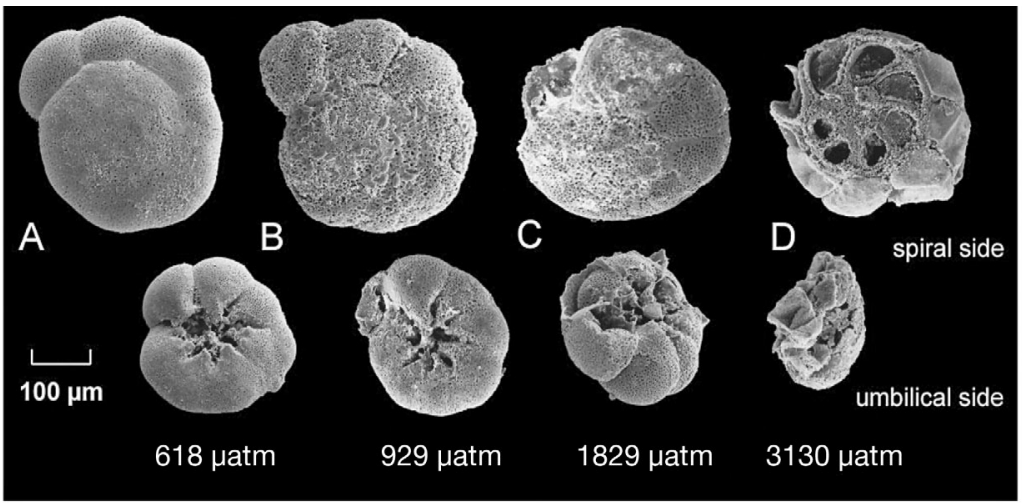

Fig. 5. Ammonia aomoriensis. SEM images depicting different stages of dissolution on spiral and umbilical sides of the test at various $\mathrm{pCO}_{2}$ levels (A to D) trapped under the lid of the vessels, thus eliminating this option. It remains possible that some of the specimens were lost during sampling.

The loss resulted in no significant difference between the active specimens of size fractions 150 to $250 \mu \mathrm{m}, 250$ to $350 \mu \mathrm{m}$ or inactive specimens $>200 \mu \mathrm{m}$. In the $\mathrm{pCO}_{2}$ range of 618 to $929 \mu \mathrm{atm}$, the losses of active and inactive specimens during the experimental period averaged from 7 to 11 of the 30 cultured specimens. Significantly higher losses were observed at a $\mathrm{pCO}_{2}$ of 3130 uatm. From 30 specimens at the beginning of the experiment, the loss of active specimens of the 150 to $250 \mu \mathrm{m}$ and 250 to $350 \mu \mathrm{m}$ size fractions averaged 18 specimens. Among the inactive specimens $>200 \mu \mathrm{m}$, an average of 22 out of 30 individuals were lost during the experiment (Fig. 4).

At the end of the experiment, the foraminifers were picked individually from the recruitment pits under water. Staining of these organisms with Rose Bengal revealed that most individuals incubated from 618 to $1829 \mu \mathrm{atm} \mathrm{pCO}_{2}$ survived. Based on staining evidence, an average of 20 active and inactive specimens from each vessel had survived the experiment. However, of the 12 specimens remaining at experiment's end that had been subjected to a $\mathrm{pCO}_{2}$ of $3130 \mu$ atm, an average of 10 contained no living cytoplasm at the end of the incubation and were presumed dead.

\section{SEM observations}

The different stages of dissolution during the $6 \mathrm{wk}$ incubation time were revealed by SEM observations (Fig. 5). The tests of Ammonia aomoriensis exposed to a $\mathrm{pCO}_{2}$ of 618 to 751 ratm were fully intact (Fig. 5A). The test walls exhibited a smooth surface, and the pore size and distribution on the shell wall remained unaffected. At $\mathrm{pCO}_{2}$ levels of 929 and 1829 patm the last 1 to 3 younger chambers were severely decalcified or destroyed (Fig. 5B,C). The surface of the walls showed

fragmentary dissolution of the younger calcite layers, which were left only as scales (Fig. 6A,B). Furthermore, at a seawater $\mathrm{pCO}_{2}$ of 1829 uatm, we observed the formation of cracks around the pores. (Fig. 6C). On some individuals, at a $\mathrm{pCO}_{2}$ of $1829 \mu \mathrm{atm}$, the SEM examination revealed prograding incisions along the sutures. At a high $\mathrm{pCO}_{2}$ of $3130 \mu \mathrm{atm}$, the tests had become heavily decalcified after 6 wk (Fig. 5D). The tests showed an irregular shape caused by dissolution of the outer chamber walls (Fig. 6D). In all cases, the shell was interrupted and only the inner organic lining remained (Fig. 5D). The interlocular walls were isolated, and their internal calcite layers were separated (Fig. 6D). The remaining interlocular walls gave the tests a star-like appearance (Fig. 5D).

\section{DISCUSSION}

\section{Change of test diameter of Ammonia aomoriensis under elevated $\mathrm{pCO}_{2}$}

The increase in average test diameter indicated that the individuals had grown during the experiment. Growth was higher among the small young and active specimens than among the large active and inactive adults. At a control $\mathrm{pCO}_{2}$ of $618 \mu \mathrm{atm}, 78 \%$ of the active specimens from the 150 to $250 \mu \mathrm{m}$ size fraction grew during the experiment, as did $65 \%$ of the specimens from the 250 to $350 \mu \mathrm{m}$ size fraction. Only $44 \%$ of inactive specimens of the $>200 \mu \mathrm{m}$ size fraction showed an increase in test diameter, which implied growth by chamber addition during the 6 wk incubation time (Table 3). Substantially more specimens grew in our experiment than during the experiments of Dissard et al. (2009), where $\sim 60 \%$ of the specimens kept at a low, pre-industrial $\mathrm{CO}_{2}$ level added new chambers. With increasing $\mathrm{pCO}_{2}$, the difference between initial and final test diameter of Ammonia aomoriensis 


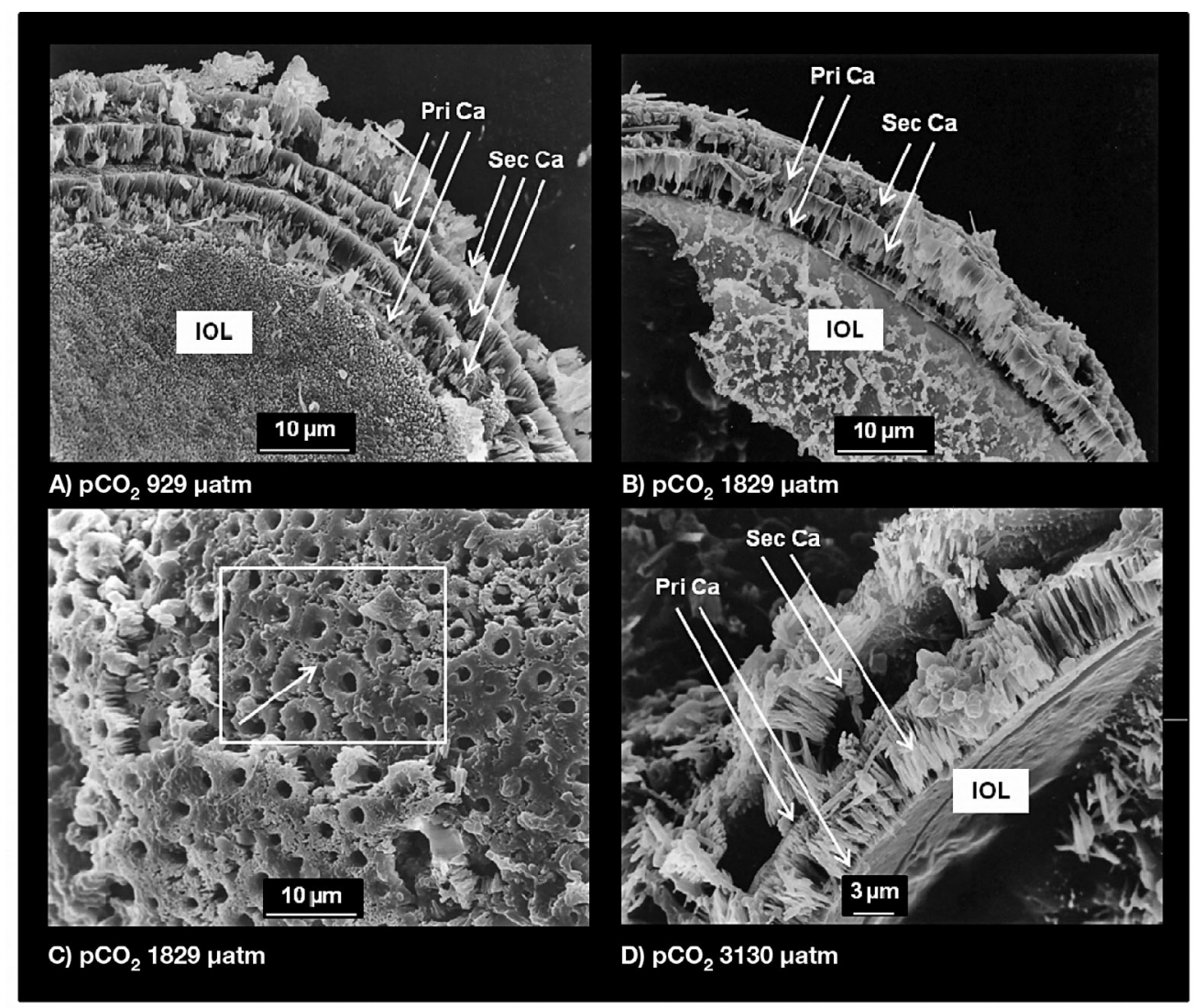

Fig. 6. Ammonia aomoriensis. (A,B,D) SEM images showing layers of primary calcite (Pri Ca), secondary calcite (Sec Ca) and inner organic lining (IOL) after 6 wk incubation under elevated $\mathrm{pCO}_{2}$. (C) Note appearance of cracks at $\mathrm{pCO}_{2}$ of $1829 \mu \mathrm{\mu tm}$

Table 3. Ammonia aomoriensis. Newly added chambers from active specimens of 3 size fractions, including both active and inactive specimens, at a control $\mathrm{pCO}_{2}$ of $618 \mu \mathrm{atm}$

\begin{tabular}{|c|c|c|c|}
\hline \multirow{2}{*}{$\begin{array}{l}\text { Number of } \\
\text { specimens }\end{array}$} & \multirow{2}{*}{\multicolumn{3}{|c|}{$\begin{array}{lc}\text { - Active specimens - Inactive specimens } \\
150-250 \mu \mathrm{m} \quad 250-350 \mu \mathrm{m} \quad>200 \mu \mathrm{m}\end{array}$}} \\
\hline & & & \\
\hline Surviving the experiment & 18 & 23 & 18 \\
\hline Showing no growth & 4 & 8 & 10 \\
\hline Grown by 1 chamber & 0 & 1 & 0 \\
\hline Grown by 2 chambers & 6 & 6 & 6 \\
\hline Grown by 3 chambers & 3 & 8 & 2 \\
\hline Grown by 4 chambers & 5 & 0 & 0 \\
\hline Average chamber addition & 2.3 & 1.6 & 1.0 \\
\hline Percentage showing growth & $78 \%$ & $65 \%$ & $44 \%$ \\
\hline
\end{tabular}

number of new chambers that had been formed during the experiment. The newly precipitated calcite of the final chambers contained calcein similar to the walls of the earlier chambers, even though it had not grown in calcein-stained water. We suppose that the calcein was incorporated and stored in vacuoles filled with seawater, from which the calcite for the new chamber wall of the foraminifer was formed. This might explain why the new chambers were fluorescent after the 6 wk incubation time without cal-

decreased. A significant reduction in foraminiferal test diameter was observed at a high $\mathrm{pCO}_{2}$ of $3130 \mu$ atm.

Foraminifera grow by adding new chambers. To assess chamber addition, specimens that had grown during the experiment were examined after the incubation time under a fluorescence microscope. All youngest chambers were stained with calcein (for comparison see Fig. 1A of Allison et al. 2010, p. 88). Since the intensity was hardly distinguishable from the elder part of the test, we could not assess with certainty the cein having been added to the percolating seawater. Another explanation might be that calcein was adsorbed to the organic lining and all calcein-stained chambers were either formed during pre-incubation time or the calcein was re-mobilised from the linings during formation of new chambers. As we observed that foraminifers were stained with calcein before placing them into culture vessels and they had definitely grown during the experiment, this explanation seems less likely. Furthermore, little is known about 
the internal dynamics and intermittent storage of calcein in living cells. Normally, calcein does not pass cell membranes. An adsorption to organic linings therefore does not appear likely.

Due to the above-mentioned constraints, chamber formation of Ammonia aomoriensis could be assessed only by means of increase in test diameter. An examination of SEM images taken from 24 specimens of A. aomoriensis sampled in Flensburg Fjord, Kiel Fjord, and Eckernförde Bight (Schönfeld \& Numberger 2007a,b, Polovodova \& Schönfeld 2008, Nikulina et al. 2008, Polovodova et al. 2009, Schweizer et al. 2010) revealed an increase in diameter (average $\pm \mathrm{SD}, \mathrm{n}=$ 12) of $27 \pm 16 \mu \mathrm{m}$ per new chamber over the last 4 chambers. The height of the last 2 chambers, as seen from the spiral side, was $106 \pm 23 \mu \mathrm{m}$. The increase in test diameter by adding new chambers did not covary with the overall diameter. Therefore we conclude that A. aomoriensis growth by 13 to $39 \mu \mathrm{m}$ at a $\mathrm{pCO}_{2}$ of $618 \mu \mathrm{atm}$ corresponded to the addition of 1 or 2 new chambers during the $6 \mathrm{wk}$ experimental period. In terms of chamber addition, active specimens of size fraction 150 to $250 \mu \mathrm{m}$ added 2.3 chambers on average, and specimens of size fraction 250 to $350 \mu \mathrm{m}$ added 1.6 new chambers. Inactive specimens added 1.0 new chamber on average (Table 3 ). An example of growth for one active individual of $A$. aomoriensis from size fraction 250 to $350 \mu \mathrm{m}$ is presented in Fig. 7. During the incubation time, this individual grew by $33 \mu \mathrm{m}$. The growth took place in 2 increments of $16 \mu \mathrm{m}$, the first between Days 7 and 14, and the second between Days 14 and 21. On the basis of the aforementioned calculations, we concluded that this specimen had added 2 new chambers at a $\mathrm{pCO}_{2}$ of $618 \mu \mathrm{atm}$.

Culture experiments assessing the growth of Ammonia aomoriensis from the western Baltic Sea have not been reported to date. The cultivation of A. tepida from San Antonio Bay, Texas, revealed a strong dependency of test growth on ambient temperature and salinity (Bradshaw, 1957). During the experimental period, we measured an average temperature of $11.7^{\circ} \mathrm{C}$ and salinity of $18.4 \mathrm{psu}$. On the basis of Bradshaw's (1957) data applied to our experimental settings, we estimated a growth rate of 0.06 chambers per day, causing us to expect an addition of 2 to 3 new chambers over $6 \mathrm{wk}$. In fact, our measurements indicated an addition of only 1 to 2 new chambers on average, which is slightly lower than could be estimated using Bradshaw's (1957) data, but it is nonetheless in general agreement with that estimate.

Dissard et al. (2009) reported that only half the specimens added new chambers during 6 wk of laboratory cultivation. Their average rates of 0.9 to 1.7 new chambers per individual fit well with our results. The culturing of the benthic foraminifer Elphidium williamsoni

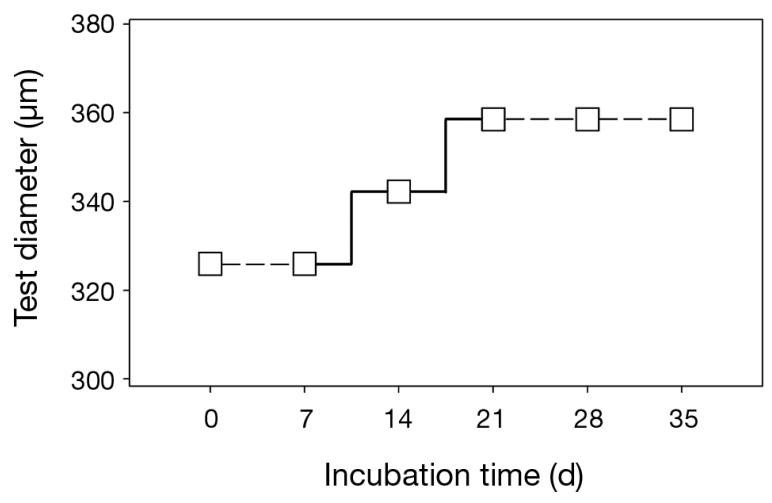

Fig. 7. Ammonia aomoriensis. Change in test diameter over time of a single active individual from size fraction 250$350 \mu \mathrm{m}$. Increment in diameter between Days 7 and 21 implies addition of 2 new chambers

showed that they formed from 1 to 3 new chambers at a pH range of 7.6 to 8.3 at $15^{\circ} \mathrm{C}$ during an 8 wk experimental period (Allison et al. 2010).

During our experimental period, we observed that tests dissolved more readily at a high seawater $\mathrm{pCO}_{2}$ than at a lower level. In our study the test diameter of Ammonia aomoriensis showed an increase with $\mathrm{pCO}_{2}$ values up to 751 uatm. Above a critical $\mathrm{pCO}_{2}$ level of $1829 \mu \mathrm{atm}$, however, dissolution features and a reduction of test diameter were observed. The inferred reduction of calcification might be a result of a presumably higher energetic cost to elevate the $\mathrm{pH}$ of intracellular vesicles where the first calcite crystals for the new chamber walls are precipitated (de Nooijer et al. 2008). This might explain the growth deceleration but not the size reduction observed at a $\mathrm{pCO}_{2}$ at $>1829 \mu \mathrm{atm}$. Alternatively, shell-wall thinning might be the result of dissolution under elevated $\mathrm{pCO}_{2}$. SEM observations revealed the outer chamber walls to be 4 to $10 \mu \mathrm{m}$ thick. Corrosion or even dissolution of the outer chamber walls would cause a reduction of the test diameter by 10 to $20 \mu \mathrm{m}$. The average chamber height is $106 \mu \mathrm{m}$. If the entire last whorl were to be dissolved, the shell loss would exceed by far the observed reduction of 23 to $49 \mu \mathrm{m}$ in diameter. Therefore, it is reasonable to assume that the size reduction was due to a loss of outer shell wall and partial collapse of inner organic lining, which is in agreement with the SEM observations of dissolution features.

\section{Dissolution features}

Our results revealed a clear relationship between seawater $\mathrm{pCO}_{2}$ and shell dissolution. The first dissolution features were recorded at a $\mathrm{pCO}_{2}$ of $929 \mu \mathrm{atm}$ and led to loss of the last-formed (thinner) chambers. At a 
$\mathrm{pCO}_{2}$ of 3130 uatm all chambers were destroyed by complete calcium carbonate dissolution, only the inner organic lining stayed intact.

Under elevated $\mathrm{pCO}_{2}$ conditions, we observed different stages of dissolution. Decalcification started with loss of the external walls of the last chambers at a $\mathrm{pCO}_{2}$ level of $929 \mu \mathrm{atm}$. The younger chambers decalcify first because their walls consist of a lower number of lamellae and therefore are thinner (Le Cadre et al. 2003). The next stage of dissolution is total decalcification of the outer walls and the inner organic lining, with cytoplasm becoming visible at a $\mathrm{pCO}_{2}$ of 3130 uatm. For instance, the individual presented in Fig. 5D had a test diameter of $342 \mu \mathrm{m}$ at the beginning, and after $6 \mathrm{wk}$ incubation at $\mathrm{pCO}_{2}$ of $3130 \mu$ atm the diameter was reduced to $32 \mu \mathrm{m}$.

The shell of foraminifers is composed of many calcitic layers - so called primary and secondary calcite-which cover the chambers (Erez 2003). The thickness of each layer depends on the number of chambers per whorl (Reiss 1957, Bentov \& Erez 2005). The needles of the primary calcite, which forms the inner lamella outlining the new chamber, usually consist of a high-Mg calcite. The secondary calcitic layer, which covers the inner lamella as well as the entire existing shell, consists of low-Mg calcite (Reiss 1957, Erez 2003). Dissolution of the secondary calcite, which is deposited among the primary calcite needles, leads to test transparency (Le Cadre et al. 2003). We even observed a scabbing of the external walls of all chambers at a $\mathrm{pCO}_{2}$ of $929 \mu \mathrm{atm}(\mathrm{pH} 7.7)$, with the primary calcite dissolving first, and needles of the secondary calcite beginning to thin (Fig. 6A). At a higher $\mathrm{pCO}_{2}$ level (1829 $\mu \mathrm{atm})$, primary calcite dissolved first and caused formation of lacunae among the needles of the first layer of secondary calcite and the inner organic lining. At the same time, the needles of the secondary calcite thinned at their base (Fig. 6B). Furthermore, the pore diameter expanded on the external walls and cracks were formed on the surface. At the highest $\mathrm{pCO}_{2}$ treatment $(3130 \mu \mathrm{atm})$, the primary calcite dissolved completely. In the first layer of secondary calcite from the inner side, the needles became generally thinner (Fig. 6D). The second layer of secondary calcite on the outer side corroded completely (Fig. 6D). In general, corroded tests became opaque. We conclude from our SEM observations that dissolution progressed both from the inner (cytoplasm) surface and the outer (seawater) surface. Acidified seawater probably diffuses through the pores from the external walls towards the inner organic lining. From the inner side the primary calcite corroded first. This is because this primary material consists of high-Mg calcite (Bentov \& Erez 2005), which is less resistant to dissolution than the needles of secondary, low-Mg calcite.
Corroded walls have likewise been observed in living Ammonia beccarii from Isle de Yeu, France (Le Cadre et al. 2003). The specimens first retarded their pseudopodial network, then the test became opaque and the youngest chambers were destroyed. After $15 \mathrm{~d}$, only the interlocular walls were preserved, and the inner organic layer covered the cytoplasm at the other parts of the test (Le Cadre et al. 2003).

The results of Le Cadre et al. (2003) demonstrate that Ammonia beccarii is able to rebuild its shells through recalcification when $\mathrm{pH}$ is increased following temporary exposure to low $\mathrm{pH}$ levels. In our laboratory experiment, however, A. aomoriensis was permanently exposed to low $\mathrm{pH}$. According to our observations, A. aomoriensis exhibited no evidence of counteracting dissolution through rebuilding its shells during the incubation time of $6 \mathrm{wk}$.

Our laboratory experiment reproduced the dissolution phenomena observed in nature. Different stages of test dissolution of Ammonia beccarii were found in Gelting Bay, Flensburg Fjord. All observed Ammonia specimens were corroded and exhibited loss of the youngest chambers or the tests took on a star-like appearance with visible inner organic linings (Polovodova \& Schönfeld 2008, Plate 3, Figs. 2-6). Similar dissolution features were observed in the following: A. batavus from Sandebukta, Oslo Fjord (Alve \& Nagy 1986); A. parkinsoniana, Elphidium excavatum and Palmerinalla palmerae from Nueces Bay, Texas (Buzas-Stephens \& Buzas 2005); tropical, intertidal benthic foraminifera from Cleveland Bay, North Queensland (Berkeley et al. 2008); and estuarine foraminifera from South Alligator River, Northern Territory, Australia (Wang \& Chappell 2001).

The dissolution features observed in nature may have a variety of anthropogenic or natural causes (Le Cadre et al. 2003). Here we can only speculate that the lowering of $\mathrm{pH}$ in seawater of natural habitats is an important factor in test dissolution. Abrasion and predation, as well as early diagenesis, were previously considered as mechanisms that may act independently or amplify each other (Bradshaw 1957, Martin et al. 1995, Alve \& Murray 1999, Moreno et al. 2007, Polovodova \& Schönfeld 2008). As these processes can be ruled out under laboratory conditions, the shell loss of cultured foraminifers can only be interpreted in light of carbonate chemistry impacts on the calcification and dissolution process (Stubbles et al. 1996a,b).

\section{Loss rate and mortality}

We observed no significant differences of loss between the active and inactive specimens. At a $\mathrm{pCO}_{2}$ of 3130 uatm, however, where significantly higher 
losses were observed, the highest loss was seen in inactive specimens $>200 \mu \mathrm{m}$, followed by small active specimens of the 150 to $250 \mu \mathrm{m}$ size fraction. Subsequent treatment with Rose Bengal demonstrated that most of the specimens were devoid of cytoplasm at a $\mathrm{pCO}_{2}$ of $3130 \mu \mathrm{atm}$. We observed that the test wall of Ammonia aomoriensis was completely destroyed at a $\mathrm{pCO}_{2}$ of $3130 \mu \mathrm{atm}$ and that only the inner organic lining was left. Therefore it is possible that the inner organic lining, which is much lighter than a calcitic test, may float easily or disappear. This may explain why we did not recover some of the specimens after 6 wk of incubation time. On the other hand, it is also possible that specimens were flushed away or escaped from the recruitment pits.

Loss and mortality rates revealed that inactive specimens or empty shells of foraminifera were affected first, followed by small active specimens of the 150 to $250 \mu \mathrm{m}$ size fraction. This indicates that living cells may be able to counteract dissolution better than dead cells, at least up to a certain $\mathrm{pCO}_{2}$ level. This emphasizes the potential for biological control, which is required to maintain inorganic tests and shells in an adverse abiotic environment.

Furthermore, we observed that the test walls of small specimens of the 150 to $250 \mu \mathrm{m}$ size class sustained greater damage at high $\mathrm{pCO}_{2}$ levels than did large specimens of the 250 to $350 \mu \mathrm{m}$ size fraction. The surface:volume ratio of small tests is greater than that of large tests. Small specimens have a relatively greater surface, which is affected by external corrosion and may therefore respond more sensitively to undersaturated conditions. Another possible reason for greater damage sustained by small specimens is the thickness of the test walls of such specimens. In comparison to adult and large specimens, young and small specimens have thinner walls and fewer calcite lamellae. Therefore, the test walls of small specimens could be more easily destroyed. Our results indicate that the test walls of Ammonia aomoriensis cracked or dissolved at the high $\mathrm{pCO}_{2}$ of $3130 \mu \mathrm{atm}$, first in inactive or dead specimens, then in small and finally in large specimens.

\section{Ecological effect}

Ammonia species are the most successful colonisers in near-coastal environments, and well-known opportunists, able to tolerate environmental stress (e.g. Almogi-Labin et al. 1995, Debenay et al. 1998, 2009). In the western Baltic Sea, A. beccarii was considered an invasive species, which arrived from the North Sea and finally colonised the area in the 20th century (Polovodova et al. 2009, Schweizer et al. 2010).
Field studies of Polovodova et al. (2009) showed fine porosity on the tests of living Ammonia from Flensburg Fjord (Stn PF16-25). In general, pores were seen to be joined in places, and tests showed signs of secondary calcification-e.g. regeneration scars. The observed porosity of Ammonia tests caused by dissolution may be explained by seasonal changes of the carbonate system under natural conditions (Table 1) and the ability of Ammonia to regenerate tests when conditions become less corrosive (Le Cadre et al. 2003). This is in contrast to the constantly elevated $\mathrm{CO}_{2}$ levels simulated in our laboratory experiment.

While open ocean $\mathrm{pCO}_{2}$ levels of 1829 ( $\mathrm{pH}$ 7.4) and 3130 ratm ( $\mathrm{pH} 7.2$ ), as produced in this study, are not projected to develop due to ocean acidification in the near future, such conditions are already prevailing today in seasonally or permanently suboxic waters, including our sampling site in Flensburg Fjord. Because of the low buffering capacity of Baltic Sea water and the widespread seasonal undersaturation of portions of its bottom waters (Thomsen et al. 2010), the Baltic Sea is considered particularly vulnerable to acidification. Based on the results of this study, the resultant reduced calcification and shell dissolution of A. aomoriensis could lead to its disappearance from the Baltic Sea during the course of this century. This will also lead to changes in the community structure of benthic foraminifera (Watkins 1961, Schafer 1973, Ellison et al. 1986, Sharifi et al. 1991, Alve 1991, Yanko et al. 1998, Thomas et al. 2000, Debenay et al. 2001) and may induce shifts in the benthic ecosystem of the SW Baltic Sea.

\section{CONCLUSIONS}

Ammonia aomoriensis exhibited reduced calcification and increased test dissolution at elevated $\mathrm{pCO}_{2}$ levels and lowered $\mathrm{pH}$. Decalcification started with loss of the outer, thinner chambers at a $\mathrm{pCO}_{2}$ of 929 uatm. Total decalcification, when chambers were destroyed and the inner organic lining became visible, began at a $\mathrm{pCO}_{2}$ of $3130 \mu \mathrm{atm}$. Our observations indicate that dissolution of calcified structures progressed both from the inner (cytoplasm) surface and the outer (seawater) surface. Primary calcite is affected before secondary calcite. Observed loss and mortality rates suggest that living cells of $A$. aomoriensis are able to withstand and cope with dissolution up to a certain $\mathrm{pCO}_{2}$ level. We have already achieved $\mathrm{pCO}_{2}$ levels in the range of from 1829 ( $\mathrm{pH} 7.4$ ) to $3130 \mu \mathrm{atm}(\mathrm{pH} 7.2$ ) during the seasonal cycle in shallow areas of Flensburg Fjord. With progressing $\mathrm{CO}_{2}$-induced acidification this may eventually lead to conditions inducing significant changes in the composition of benthic foraminiferal 
communities in our study area as well as in other regions experiencing naturally high bottom-water $\mathrm{pCO}_{2}$ levels.

Acknowledgements. This study was funded by the Excellence Cluster 'Future Ocean' of Kiel University (grant no. CP 0801). We thank P. Fritsche for assistance in determination of nutrients, M. Wahl for providing working space and J. Thomsen and A. Form for help with planning the experimental setup. We gratefully acknowledge the encouragement and advice of C. Barras of the University of Angers, France; J. Bijma and L. de Nooijer of the AWI Bremerhaven, Germany; and J. Erez of the Hebrew University, Israel.

\section{LITERATURE CITED}

Allison N, Austin W, Paterson D, Austin H (2010) Culture studies of the benthic foraminifera Elphidium williamsoni: Evaluating $\mathrm{pH}, \Delta\left[\mathrm{CO}_{3}{ }^{2-}\right]$ and inter-individual effects on test Mg/Ca. Chem Geol 274:87-93

Almogi-Labin A, Siman-Tov R, Rosenfeld A, Debard E (1995) Occurrence and distribution of the foraminifer Ammonia beccarii tepida (Cushman) in water bodies, recent and quaternary, of the Dead Sea rift, Israel. Mar Micropaleontol 26:153-159

Alve E (1991) Benthic foraminifera in sediment cores reflecting heavy metal pollution in Sorfjord, Western Norway. J Foraminiferal Res 21:1-19

Alve E, Murray JW (1999) Marginal marine environments of the Skagerrak and Kattegat: a baseline study of living (stained) benthic foraminiferal ecology. Palaeogeogr Palaeoclimatol Palaeoecol 146:171-193

Alve E, Nagy J (1986) Estuarine foraminiferal distribution in Sandebukta, a branch of the Oslo Fjord. J Foraminiferal Res 16:261-284

Asano K (1951) Rotaliidae. In: Stach LW (ed) Illustrated catalogue of Japanese Tertiary smaller foraminifera. Hosokawa Printing, Tokyo, p 1-21

Barras C, Geslin E, Duplessey JC, Jorissen FJ (2009) Reproduction and growth of the deep-sea benthic foraminifer Bulimina marginata under different laboratory conditions. J Foraminiferal Res 39:155-165

Bentov S, Erez J (2005) Novel observations on biomineralization processes in foraminifera and implications for $\mathrm{Mg} / \mathrm{Ca}$ ratio in the shells. Geology 33:841-844

Berkeley A, Perry CT, Smithers SG, Horton BP (2008) The spatial and vertical distribution of living (stained) benthic foraminifera from a tropical, intertidal environment, north Queensland. Australia. Mar Micropaleontol 69:240-261

Bernhard JM, Blanks JK, Hintz CJ, Chandler GT (2004) Use of the fluorescent calcite marker calcein to label foraminiferal tests. J Foraminiferal Res 34:96-101

Bijma J, Spero HJ, Lea DW (1999) Reassessing foraminiferal stable isotope geochemistry: impact of the oceanic carbonate system (experimental results). In: Fisher G, Wefer G (eds) Use of proxies in paleoceanography: examples from the South Atlantic. Springer, Heidelberg, p 489-512

Borges AV, Gypens N (2010) Carbonate chemistry in the coastal zone responds more strongly to eutrophication than ocean acidification. Limnol Oceanogr 55:346-353

Bouchet VMP, Debenay JP, Sauriau PG, Radford-Knoery J, Soletchnik P (2007) Effects of short-term environmental disturbances on living benthic foraminifera during the Pacific oyster summer mortality in the Marennes-Oléron Bay (France). Mar Environ Res 64:358-383
Bradshaw J (1957) Laboratory studies on the rate of growth of the foraminifer Streblus beccarii (Linné) var. tepida (Cushman). J Paleontol 31:1138-1147

Buzas-Stephens P, Buzas MA (2005) Population dynamics and dissolution of foraminifera in Nueces Bay. Texas. J Foraminiferal Res 35:248-258

Caldeira K, Wickett ME (2005) Ocean model predictions of chemistry changes from carbon dioxide emissions to the atmosphere and ocean. J Geophys Res 110:C09S04, doi: 10.1029/2004JC002671

Cao L, Caldeira K (2008) Atmospheric $\mathrm{CO}_{2}$ stabilization and ocean acidification. Geophys Res Lett 35:L19609, doi: 10.1029/2008GL035070

> Conley DJ, Carstensen J, Ærtebjerg G, Christensen PB, Dalsgaard T, Hansen JLS, Josefson AB (2007) Long-term changes and impacts of hypoxia in Danish coastal waters. Ecol Appl 17:S165-S184

Conley DJ, Björck S, Bonsdorff E, Carstensen J and others (2009) Hypoxia-related processes in the Baltic Sea. Environ Sci Technol 43:3412-3420

Corliss BH (1985) Microhabitats of benthic foraminifera within deep-sea sediments. Nature 314:435-438

Cossellu M, Nordberg K (2010) Recent environmental changes and filamentous algal mats in shallow bays on the Swedish west coast: A result of climate change? J Sea Res 63:202-212

Cushman JA (1926) Recent foraminifera from Porto Rico. Carnegie Inst Washington Publ 342:73-84

de Nooijer LJ, Toyofuku T, Oguri K, Nomaki H, Kitazato H (2008) Intracellular $\mathrm{pH}$ : distribution in foraminifera determined by the fluorescent probe HPTS. Limnol Oceanogr Methods 6:610-618

Debenay JP, Beneteau E, Zhang J, Stouff V, Geslin E, Redois F, Fernandez-Gonzalez M (1998) Ammonia beccarii and Ammonia tepida (Foraminifera): morphofunctional arguments for their distinction. Mar Micropaleontol 34: 235-244

> Debenay JP, Tsakiridis E, Soulard R, Grossel H (2001) Factors determining the distribution of foraminiferal assemblages in Port Joinville Harbour (lle d'Yeu, France): the influence of pollution. Mar Micropaleontol 43:75-118

Debenay JP, Della Patrona L, Goguenheim H (2009) Colonization of coastal environments by foraminifera: insight from shrimp ponds in New Caledonia (SW Pacific). J Foraminiferal Res 39:249-266

> Diaz RJ, Rosenberg R (2008) Spreading dead zones and consequences for marine ecosystems. Science 321:926-929

> Dickson AG (1981) An exact definition of total alkalinity and a procedure for the estimation of alkalinity and total inorganic carbon from titration data. Deep-Sea Res A 28: $609-623$

> Dickson AG, Millero FJ (1987) A comparison of the equilibrium constants for the dissociation of carbonic acid in seawater media. Deep-Sea Res A 34:1733-1743

> Dissard D, Nehrke G, Reichart GJ, Bijma J (2009) Impact of seawater $\mathrm{pCO}_{2}$ changes on calcification and on $\mathrm{Mg} / \mathrm{Ca}$ and $\mathrm{Sr} / \mathrm{Ca}$ in benthic foraminifera calcite (Ammonia tepida): results from culturing experiments. Biogeosciences Discuss 6:3771-3802

Ellison R, Broome R, Ogilvie R (1986) Foraminiferal response to trace metal contamination in the Patapsco River and Baltimore Harbour, Maryland. Mar Pollut Bull 17:419-423

Erez J (2003) The source of ions for biomineralization in foraminifera and their implications for paleoceanographic proxies. Rev Mineral Geochem 54:115-149

> Feely RA, Sabine CL, Lee K, Berelson W, Kleypas J, Fabry VJ, Millero FJ (2004) Impact of anthropogenic $\mathrm{CO}_{2}$ on the 
$\mathrm{CaCO}_{3}$ system in the oceans. Science 305:362-366

Haake FW (1962) Untersuchungen an der ForaminiferenFauna im Wattgebiet zwischen Langeoog und dem Festland. Meyniana 12:25-64

Hansen HP, Giesenhagen HC, Behrends G (1999) Seasonal and long-term control of the bottom water oxygen deficiency in a stratified shallow water coastal system. J Mar Sci 56:65-71

Hayward BW, Buzas MA, Buzas-Stephens P, Holzmann M (2003) The lost types of Rotalia beccarii var. tepida Cushman 1926. J Foraminiferal Res 33:352-354

- Hayward BW, Holzmann M, Grenfell HR, Pawlowski J (2004) Morphological distinction of molecular types in Ammonia: towards a taxonomic revision of the world's most common and misidentified foraminifera. Mar Micropaleontol 50: $237-271$

Heinz P, Geslin E, Hemleben C (2005) Laboratory observations of benthic foraminiferal cysts. Mar Biol Res 1:49-159

Hintz CJ, Chandler GT, Bernhard JM, McCorkle DC, Havach SM, Blanks JK, Shaw TJ (2004) A physicochemically constrained seawater culturing system for production of benthic foraminifera. Limnol Oceanogr Methods 2:160-170

Khatiwala S, Primeau F, Hall T (2009) Reconstruction of the history of anthropogenic $\mathrm{CO}_{2}$ concentrations in the ocean. Nature 462:346-350

Koroleff F (1983) Determination of nutrients. In: Grasshoff K, Ehrhardt M, Kremling K (eds) Methods of seawater analysis. Verlag Chemie, Weinheim, p 125-187

Kuhn G, Dunker E (1994) Der Minicorer, ein Gerät zur Beprobung der Sediment/Bodenwasser-Grenze. Greifswalder Geowissenschaftliche Beiträge 2:99-100

Kuroyanagi A, Kawahata H, Suzuki A, Fujita K, Irie T (2009) Impacts of ocean acidification on large benthic foraminifers: results from laboratory experiments. Mar Micropaleontol 73:190-195

Langdon C, Atkinson MJ (2005) Effect of elevated $\mathrm{pCO}_{2}$ on photosynthesis and calcification of corals and interactions with seasonal change in temperature/irradiance and nutrient enrichment. J Geophys Res 110:C09S07, doi: 10.1029/2004JC002576

Langer MR (2008) Assessing the contribution of foraminiferan protists to global ocean carbonate production. J Eukaryot Microbiol 55:163-169

> Langer MR, Silk MT, Lipps JH (1997) Global ocean carbonate and carbon dioxide production: the role of reef foraminifera. J Foraminiferal Res 27:271-277

> Le Cadre V, Debenay JP, Lesourd M (2003) Low pH effects on Ammonia beccarii test deformation: implications for using test deformations as a pollution indicator. J Foraminiferal Res 33:1-9

Lee JJ, Anderson OR (1993) Biology of foraminifera. Academic Press, London

Lehmann G (2000) Vorkommen, Populationsentwicklung, Ursache fleckenhafter Besiedlung und Fortpflanzungsbiologie von Foraminiferen in Salzwiesen und Flachwasser der Nord- und Ostseeküste Schleswig-Holsteins. $\mathrm{PhD}$ thesis, Universität Kiel, available at http://eldiss.unikiel.de/ macau/receive/dissertation_diss_00000413

Levin LA, Ekau W, Gooday AJ, Jorissen F and others (2009) Effects of natural and human-induced hypoxia on coastal benthos. Biogeosciences 6:2063-2098

Lewis E, Wallace DWR (1998) Program developed for $\mathrm{CO}_{2}$ system calculations, ORNL/CGIAC-105. Oak Ridge National Laboratory, US Department of Energy

Linné C (1758) Systema naturæ per regna tria naturæ, secundum classes, ordines, genera, species, cum characteribus, differentiis, synonymis, locis. Tomus I. Editio decima, reformata. Laurentii Salvii, Holmiæ. 10th edn, p 824

Lutze GF (1965) Zur Foraminiferen-Fauna der Ostsee. Meyniana 15:75-142

Lutze GF (1987) Benthische Foraminiferen: Vertikale Verteilung in den obersten Sedimentlagen und Probleme bei der Entnahme von Standard-Proben. Sonderforschungsbereich 313 der Universität Kiel 6:79-87

Martin RE, Harris MS, Liddell WD (1995) Taphonomy and time-averaging of foraminiferal assemblages in Holocene tidal flat sediments, Bahia la Choya, Sonora, Mexico (northern Gulf of California). Mar Micropaleontol 26: 187-206

> Mehrbach C, Culberso CH, Hawley JE, Pytkowic RW (1973) Measurement of the apparent dissociation-constants of carbonic acid in seawater at atmospheric-pressure. Limnol Oceanogr 18:897-907

Moreno J, Valente T, Moreno F, Fatela F, Guise L, Patinha C (2007) Occurrence of calcareous foraminifera and calcitecarbonate equilibrium conditions: a case study in Minho/ Coura estuary (north Portugal). Hydrobiologia 587: $177-184$

> Moy AD, Howard WR, Bray SG, Trull TW (2009) Reduced calcification in modern Southern Ocean planktonic foraminifera. Nat Geosci 2:276-280

Murray JW (1991) Ecology and paleoecology of benthic foraminifera. Longman, Harlow

Nikulina A, Polovodova I, Schönfeld J (2008) Foraminiferal response to environmental changes in Kiel Fjord, SW Baltic Sea. Earth (Waukesha) 3:37-49

$>$ Orr JC, Fabry VJ, Aumont O, Bopp L and others (2005) Anthropogenic ocean acidification over the twenty-first century and its impact on calcifying organisms. Nature 437:681-686

$>$ Pascal PY, Dupuy C, Richard P, Niquil N (2008) Bacterivory in the common foraminifer Ammonia tepida: isotope tracer experiment and the controlling factors. J Exp Mar Biol Ecol 359:55-61

Polovodova I, Schönfeld J (2008) Foraminiferal test abnormalities in the western Baltic Sea. J Foraminiferal Res 38: 318-336

Polovodova I, Nikulina A, Schönfeld J, Dullo WCh (2009) Recent benthic foraminifera in the Flensburg Fjord. J Micropaleontol 28:131-142

Reiss Z (1957) The Bilamellidea, nov. superfam. and remarks on Cretaceaous Globorotaliids. J Foraminiferal Res 8: $127-145$

Riebesell U, Zondervan I, Rost B, Tortell PD, Zeebe RE, Morel FMM (2000) Reduced calcification of marine plankton in response to increased atmospheric $\mathrm{CO}_{2}$. Nature 407 : 364-367

Rosenberg R (1985) Eutrophication: The future marine coastal nuisance? Mar Pollut Bull 16:227-231

Rottgardt D (1952) Mikropaläontolgische wichtige Bestandteile rezenter brackischer Sedimente an den Küsten Schleswig-Holsteins. Meyniana 1:169-228

Sabine CL, Feely RA, Gruber N, Key RM and others (2004) The oceanic sink for anthropogenic $\mathrm{CO}_{2}$. Science 305: $367-371$

Schafer CT (1973) Distribution of foraminifera near pollution sources in Chaleur Bay. Water Air Soil Pollut 2:219-233

> Schiebel R (2002) Planktic foraminiferal sedimentation and the marine calcite budget. Global Biogeochem Cycles 16:1065, doi:10.1029/2001GB001459

- Schnitker D (1974) Ecotypic variation in Ammonia beccarii (Linné). J Foraminiferal Res 4:217-223

> Schönfeld J, Numberger L (2007a) Seasonal dynamics and decadal changes of benthic foraminiferal assemblages in 
the western Baltic Sea (NW Europe). J Micropaleontol 26:47-60

Schönfeld J, Numberger L (2007b) The benthic foraminiferal response to the 2004 spring bloom in the western Baltic Sea. Mar Micropaleontol 65:78-95

Schweizer M, Polovodova I, Nikulina A, Schönfeld J (2010) Molecular identification of Ammonia and Elphidium species (Formaninifera, Rotaliida) from the Kiel Fjord (SW Baltic Sea) with rDNA sequences. Helgol Mar Res 65:1-10

Sharifi AR, Croudace LW, Austin RL (1991) Benthic foraminiferids as pollution indicators in Southampton Water, southern England, UK. J Micropaleontol 10:109-113

Solomon S, Qin D, Manning M, Chen Z, Marquis M (eds) (2007) Contribution of Working Group I to the Fourth Assessment Report of the Intergovernmental Panel on Climate Change. Cambridge University Press, New York

Spero HJ, Bijma J, Lee DW, Bemis BE (1997) Effect of seawater carbonate concentration on foraminiferal carbon and oxygen isotopes. Nature 390:497-500

Stubbles SJ, Green JC, Hart MB, Williams CL (1996a) The ecological and palaeoecological implications of the presence and absence of data: evidence from benthic foraminifera. Proc Ussher Soc 9:54-62

Stubbles SJ, Hart MB, Williams CL, Green JC (1996b) Responses of foraminifera to presence of heavy metal contamination and acidic mine drainage. Conference on minerals, metals and the environment II. Institution of Mining and Metallurgy, Prague, p 217-235

Takahashi $\mathrm{T}$ (2004) The fate of industrial carbon dioxide. Science 305:352-353

Thomas E, Gapotchenko T, Varekamp EC, Mecray EL, Buchholtz ten Brink MR (2000) Maps of benthic foraminiferal

Editorial responsibility: Hans Heinrich Janssen, Oldendorf/Luhe, Germany distribution and environmental changes in Long Island Sound between the 1940s and the 1990s. In: Paskevich VF, Poppe LJ (eds) US Geological Survey Open-File Report 00-304, chap. 9. USGS, Woods Hole, MA, available at http://pubs.usgs.gov/of/2000/of00-304/htmldocs/chap09/ index.htm

Thomsen J, Melzner F (2010) Moderate seawater acidification does not elicit long-term metabolic depression in the blue mussel Mytilus edulis. Mar Biol 157:2667-2676

Thomsen J, Gutowska MA, Saphörster J, Heinemann A and others (2010) Calcifying invertebrates succeed in a naturally $\mathrm{CO}_{2}$-rich coastal habitat but are threatened by high levels of future acidification. Biogeosciences 7 : 3879-3891

Wang P, Chappell J (2001) Foraminifera as Holocene environmental indicators in the South Alligator River, northern Australia. Quat Int 83-85:47-62

Watkins JG (1961) Foraminiferal ecology around the Orange County, California, ocean sewer outfall. Micropaleontology 7:199-206

Wefer G (1976) Umwelt, Produktion und Sedimentation benthischer Foraminiferen in der westlichen Ostsee. Reports Sonderforschungsbereich 95 Wechselwirkung Meer-Meeresboden 14:1-103

Yanko V, Ahmad M, Kaminski M (1998) Morphological deformities of benthic foraminiferal tests in response to pollution by heavy metals: implications for pollution monitoring. J Foraminiferal Res 28:177-200

Zhang J, Gilbert D, Gooday AJ, Levin L and others (2010) Natural and human-induced hypoxia and consequences for coastal areas: synthesis and future development. Biogeosciences 7:1443-1467

Submitted: August 31, 2010; Accepted: March 17, 2011 Proofs received from author(s): June 10, 2011 